\title{
Role of complement in IgA nephropathy
}

\author{
Mohamed R. Daha ${ }^{1} \cdot$ Cees van Kooten ${ }^{1}$
}

Received: 20 October 2015/Accepted: 26 October 2015/Published online: 13 November 2015

(C) The Author(s) 2015. This article is published with open access at Springerlink.com

\begin{abstract}
Immunoglobulin A nephropathy (IgAN) is characterized by the deposition of IgA in the mesangium of glomeruli. This mesangial IgA has been found to consist mainly of polymeric IgA1 which drives the activation of the mesangial cells and results in excessive production of several inflammatory mediators. The activation of mesangial cells is amplified by the ability of IgA to activate the complement system, originally thought to occur mainly via the alternative pathway of complement. However more recent studies indicate that lectin pathway involvement has a strong association with progression of renal disease. In this review we summarize the contribution of complement to the IgA- mediated inflammatory process.
\end{abstract}

Keywords $\operatorname{IgA}$ nephropathy $\cdot$ Complement $\cdot \mathrm{MBL} \cdot \mathrm{C} 4 \mathrm{~d}$

\section{Introduction}

Immunoglobulin A nephropathy (IgAN) is characterized by the deposition of $\operatorname{IgA}$ in the mesangium of glomeruli. This mesangial IgA has been found to consist mainly of polymeric IgA1 which drives the activation of the mesangial cells and results in excessive production of several inflammatory mediators. The activation of mesangial cells is amplified by the ability of $\operatorname{IgA}$ to activate the complement system, originally thought to occur mainly via the alternative pathway of complement. However, more recent studies indicate that lectin pathway involvement has a

Cees van Kooten

kooten@lumc.nl

1 Department of Nephrology, Leiden University Medical Center, Albinusdreef 2, 2333ZA Leiden, The Netherlands strong association with progression of renal disease. In this review, we summarize the contribution of complement to the IgA- mediated inflammatory process.

\section{The complement system}

Complement activation proceeds via three known pathways $[1,2]$. Initiation of these pathways occurs by pattern recognition. Activation of the classical pathway takes place after binding of the first component of complement $\mathrm{C} 1$ to, for instance, immune complexes. Activated $\mathrm{C} 1$ then leads to activation of its natural substrates, $\mathrm{C} 4$ and $\mathrm{C} 2$, and the generation of activator-bound $\mathrm{C} 4 \mathrm{~b} 2 \mathrm{a}$, the classical pathway $\mathrm{C} 3$ convertase, which is able to cleave $\mathrm{C} 3$ into $\mathrm{C} 3 \mathrm{~b}$ and $\mathrm{C} 3 \mathrm{a}$. C3b has the ability to attach itself in a covalent fashion to the activator or to neighbouring tissue or cells. The generation of $\mathrm{C} 3 \mathrm{~b}$ is one of the most important steps in complement activation and function because it allows recognition of foreign pathogens or immune complexes with cellular elements of our defence systems via specific interaction with cellular $\mathrm{C} 3$ receptors. There are a number of receptors for activated $\mathrm{C} 3$, such as the receptor for $\mathrm{C} 3 \mathrm{~b}$ (CD35), iC3b (CR3) and for C3dg (CD21). CD35 is mainly found on primate erythrocytes where it plays an essential role in the binding and proper handling of circulating immune complexes. The conversion of activator-bound $\mathrm{C} 3 \mathrm{~b}$ to $\mathrm{iC} 3 \mathrm{~b}$ by inhibitors like factor $\mathrm{I}$ and $\mathrm{H}$ allows a pathogen or immune complex that has been opsonized with $\mathrm{iC} 3 \mathrm{~b}$ to be recognized by specific phagocytic receptors on, for instance, macrophages or polymorphonuclear leukocytes. This is a very important step in complement activation because it contributes to the elimination of foreign pathogens or self-debris by the innate immune system. Therefore, deficiencies in $\mathrm{C} 3$ are associated with different 
bacterial infections. The further breakdown of activatorbound $\mathrm{C} 3$ to $\mathrm{C} 3 \mathrm{dg}$ adds another dimension to complementmediated defence. Antigens that are opsonized with C3dg are recognized to a much better extent by follicular B cells and antigen-presenting cells, leading to initiation of an efficient acquired immune response. It was noted already back in the " $70 \mathrm{~s}$ that $\mathrm{C} 3$ activation is essential for an optimal antibody response against foreign antigens. Additionally, several studies during the past decades have shown the importance of $\mathrm{C} 3$ fragments in the shaping of the acquired immune repertoire [3].

The activation of C3 can also occur via the lectin pathway. In this pathway, targets of the lectin pathway can be recognized by the pattern-like recognition molecule mannan-binding lectin (MBL) or the Ficolins, which recognize specific carbohydrate moieties on lectin pathway activators. The binding of MBL or Ficolins to activators results in the activation of MBL-associated serum proteases like MASP-2, which then induce the activation of $\mathrm{C} 4$ and $\mathrm{C} 2$ and the generation of $\mathrm{C} 4 \mathrm{bC} 2 \mathrm{a}$. This enzyme is the same as the one generated by the activation of the classical pathway. Next to the initiation of the $\mathrm{CP}$ by immune complexes also other agents like C-reactive protein (CRP), the long pentraxin-3 (PTX3), SIGN-R1 (a lectin that binds to microbial saccharides in the spleen and phosphatidyl serine that is exposed on apoptotic cells or on self-debris). While MBL reacts with mannose residues and sugars like $\mathrm{N}$-acetyl-D-glucosamine, Ficolin-2 and Ficolin-3 recognize more specifically acetyl groups. Therefore these complement initiation/activation components can be regarded as specific soluble pattern recognition molecules that distinguish in the first place self from non-self and in addition can recognize 'altered self' such as modified self-tissue following apoptosis or modulation of the carbohydrate landscape on host tissue altered by reduced oxygen preside followed by re-oxygenation. This mechanism of complement activation could play an important role in activation of complement by apoptotic or necrotic tissue and amplify IgA-mediated renal damage.

A third pathway of complement is thought to be initiated by the slow and continuous turnover of the central component of complement $\mathrm{C} 3$. The initially generated $\mathrm{C} 3 \mathrm{~b}$ then reacts directly via its labile thio-ester with complementactivating structures. Once $\mathrm{C} 3 \mathrm{~b}$ is deposited on an activator, e.g. on specific microorganisms or cells and tissue, it can interact directly with factors $\mathrm{B}$ and $\mathrm{D}$ to form a labile $\mathrm{C} 3 \mathrm{bBb}$ convertase (the amplification $\mathrm{C} 3$-convertase) that can cleave additional C3 molecules. This inherently labile $\mathrm{C} 3 \mathrm{bBb}$ convertase can be stabilized by Properdin $(\mathrm{P})$ which enhances the $\mathrm{C} 3$ activation potential of the $\mathrm{C} 3 \mathrm{bBb}$ convertase and propels deposition of large numbers of covalently bound $\mathrm{C} 3 \mathrm{~b}$ molecules on the alternative pathway activator. Recent studies have indicated that next to direct binding of $\mathrm{C} 3 \mathrm{~b}$ to the activator, complement activation can be focused on a substance by Properdin itself. Elegant studies by Hourcade and colleagues have highlighted that Properdin can bind directly to a large number of bacteria [4]. Once Properdin is bound, and since $\mathrm{P}$ can easily polymerize, it can then recruit $\mathrm{C} 3 \mathrm{~b}$ and focus $\mathrm{C} 3$-amplification directly on pathogens or injured tissue and facilitate their interaction with cellular C3-receptors and subsequent elimination. It is therefore clear that the three pathways of the complement system are all initiated by a pattern-like recognition process involving soluble pattern-like molecules such as C1q, MBL, Ficolins and Properdin.

Independently of the initiation of complement activation, all three pathways and the two important convertases that are generated, i.e. $\mathrm{C} 4 \mathrm{~b} 2 \mathrm{a}$ and $\mathrm{C} 3 \mathrm{bBb}$, lead to the most important steps in complement activation, namely activation of $\mathrm{C} 3$ into $\mathrm{C} 3 \mathrm{~b}$ and $\mathrm{C} 3 \mathrm{a}$. Once sufficient $\mathrm{C} 3 \mathrm{~b}$ is generated by any of the three pathways, the formation of the membrane attack complex $\mathrm{C} 5 \mathrm{~b}-\mathrm{C} 9$, also called terminal complement complex (TCC) or membrane attack complex (MAC), can take place. Generation of the terminal complement pathway is associated with the formation of C5a which is a highly chemotactic fragment of C5a and which is additionally responsible for the activation of phagocytic cells like poly-morphonuclear leukocytes.

The C5b-9- complex was initially thought to be involved mainly in the cytoxic process of either foreign complement activating pathogens or host cells. More recent studies have shown that low numbers of C5b-9 induce activation of host cells leading to enhanced production of cytokines and chemokines and upregulation of adherence molecules such as LFA-1 [5]. Intermediate amounts of C5b-9 induce apoptosis of host cells and in this regard play a role in tissue turnover and homeostasis.

Activation of $\mathrm{C} 3$ results in the covalent binding of large numbers of $\mathrm{C} 3 \mathrm{~b}$ molecules to cells and tissue. This brings these cells into direct interaction with cellular $\mathrm{C} 3 \mathrm{~b}$ receptors (CR1, CD35). In plasma there are two regulators of C3 activation, namely factor $\mathrm{I}$ and factor $\mathrm{H}$, that are able to convert $\mathrm{C} 3 \mathrm{~b}$ into iC $3 \mathrm{~b}$. iC $3 \mathrm{~b}$ interacts strongly with $\mathrm{C} 3$ receptors like CR3. As mentioned, these receptors are found mainly on phagocytic cells such as macrophages and PMNs. Via these receptors iC $3 b$ bearing pathogens can be phagocytosed. During this process several inflammatory mediators are formed that can enhance the injury of cells and tissue (Fig. 1).

\section{Mechanisms of complement activation in IgAN}

While deposition of $\operatorname{IgA}$, mostly high molecular weight $\operatorname{IgA} 1$, in the renal mesangium is the hallmark of this disease, also deposition of $\mathrm{C} 3$ is a universal characteristic 

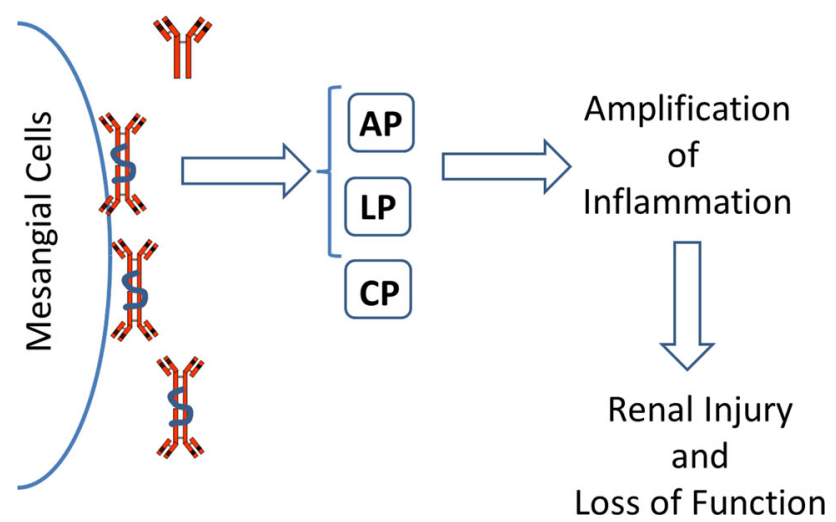

Fig. 1 Complement in IgAN. Schematic view how deposition of high MW IgA deposited in the mesangial area of the kidney can activate the complement system through either the lectin or the alternative pathway. This will amplify the local inflammatory response and contribute to renal injury and loss of function. $A P$ alternative pathway, $L P$ lectin pathway, $C P$ classical pathway, $M W$ molecular weight, $\operatorname{IgA}$ immunoglobulin A

observed in these renal biopsies. Since IgG and C1q were observed only occasionally, the origin of this complement activation was originally linked mostly to the alternative pathway [6]. However, several recent findings have shed new light on this issue.

Following the notion that $\operatorname{IgA}$, especially in its high molecular weight form, is able to activate complement via the lectin pathway, also mediators of the MBL pathway have been analysed [7, 8]. Indeed, MBL deposition has been observed in 20-25\% of cases, and cases with MBL deposition showed more renal injury and more proteinuria [9]. Several studies have now confirmed this finding, especially making use of $\mathrm{C} 4 \mathrm{~d}$, a biomarker particularly well known in transplantation, where it is thought to be a more stable marker in tissue $[8,10]$. In a large Spanish cohort, long-term prognosis in a 20-year follow up was significantly worse in those patients who showed $\mathrm{C} 4 \mathrm{~d}$ in their biopsy at the moment of diagnosis [11].

An intriguing unresolved issue is the general belief that altered O-linked glycosylation of $\operatorname{IgA} 1$ is a key step in the pathogenesis [12]. Although MBL is a lectin, it does not interact with the O-linked sugars. Therefore, the molecular explanation for interaction of MBL with $\operatorname{IgA}$ remains unclear. Based on this altered glycosylation, there is now compelling evidence that these altered IgA1 molecules can induce the formation of $\mathrm{IgG}$ autoantibodies directed against this deglycosylated hinge region. This could result in the formation of immune-complexes; however, it remains unclear how this contributes to complement activation in the kidney, since both $\mathrm{Clq}$ and $\mathrm{IgG}$ deposits are rare events. Interestingly we previously showed that renal deposits also contain secretory IgA in a small percentage of cases and that deposition of SIgA co-localizes with MBL and C4d [13]. This indicates that also other associated molecules (in this case the heavily glycosylated secretory component) can contribute to complement activation. The link with SIgA could be of importance, since SIgA is generated at mucosal surfaces and, clinically, flares of IgAN are associated with upper respiratory tract infections [14].

\section{A role for complement regulators}

In recent years, initiated by the findings of large genetic genome-wide association study (GWAS) screening [1517], attention has not only focused on the initiating routes of complement, but also on the regulators. Especially at the level of $\mathrm{C} 3$ there are multiple regulatory proteins, either membrane bound or in a soluble form. Important insights have been obtained in atypical hemolytic-uremic syndrome (aHUS) and other diseases related to uncontrolled alternative pathway activation, especially concerning the role of factor $\mathrm{H}$ and the factor $\mathrm{H}$ related proteins (CFHR) [18]. In GWAS analysis, it was found that deletion of CFHR1CFHR3 was protective in IgAN [16]. These related molecules are considered a competitor for factor $\mathrm{H}$ and therefore might directly affect factor $\mathrm{H}$ function. However, precise understanding of how this deletion would impact IgAN is not clear [19]. Interestingly, the same deletion of this locus is seen as a risk factor for the development of aHUS and the development of anti-factor $\mathrm{H}$ antibodies [18].

\section{Concluding remarks}

Over the past decade, there has been a growing interest in understanding the role of complement in the pathogenesis of IgAN. Several reasons have sparked this interest: identification of the lectin pathway as a possible contributor (with $\mathrm{C} 4 \mathrm{~d}$ as a biomarker), genetic analysis pointing towards alternative pathway regulation as a protective factor, and the availability of a therapeutic agent to interfere with the terminal route of complement activation. Irrespective of the route of activation, the effector mechanism of the terminal pathway is in common. Indeed C5b-9 deposition and appearance in the urine have been described [20]. In a recent case report, C5 blockade with eculuzimab was described [21]. Although an important observation, more research is required before complement inhibition can be more widely applied in the treatment of IgAN.

\section{Compliance with ethical standards}

Conflict of interest The authors declare no conflict of interest. 
Ethical statement Described results do not include studies with human beings or animals, and informed consent was not required.

Open Access This article is distributed under the terms of the Creative Commons Attribution 4.0 International License (http://crea tivecommons.org/licenses/by/4.0/), which permits unrestricted use, distribution, and reproduction in any medium, provided you give appropriate credit to the original author(s) and the source, provide a link to the Creative Commons license, and indicate if changes were made.

\section{References}

1. Garred P, Honore C, Ma YJ, Munthe-Fog L, Hummelshoj T (2009) MBL2, FCN1, FCN2 and FCN3-The genes behind the initiation of the lectin pathway of complement. Mol Immunol 46(14):2737-2744

2. Gorsuch WB, Chrysanthou E, Schwaeble WJ, Stahl GL (2012) The complement system in ischemia-reperfusion injuries. Immunobiology 217(11):1026-1033

3. Dempsey PW, Allison ME, Akkaraju S, Goodnow CC, Fearon DT (1996) C3d of complement as a molecular adjuvant: bridging innate and acquired immunity. Science 271:348-350

4. Kemper C, Atkinson JP, Hourcade DE (2010) Properdin: emerging roles of a pattern-recognition molecule. Annu Rev Immunol 28:131-155

5. Nauta AJ, Daha MR, van Kooten C, Roos A (2003) Recognition and clearance of apoptotic cells: a role for complement and pentraxins. Trends Immunol 24:148-154

6. Floege J, Moura IC, Daha MR (2014) New insights into the pathogenesis of IgA nephropathy. Semin Immunopathol 36(4):431-442

7. Endo M, Ohi H, Ohsawa I, Fujita T, Matsushita M, Fujita T (1998) Glomerular deposition of mannose-binding lectin (MBL) indicates a novel mechanism of complement activation in IgA nephropathy. Nephrol Dial Transplant 13(8):1984-1990

8. Maeng YI, Kim MK, Park JB, Cho CH, Oh HK, Sung WJ, Park KK (2013) Glomerular and tubular C4d depositions in IgA nephropathy: relations with histopathology and with albuminuria. Int J Clin Exp Pathol 6(5):904-910

9. Roos A, Rastaldi MP, Calvaresi N, Oortwijn BD, Schlagwein N, van Gijlswijk-Janssen DJ, Stahl GL, Matsushita M, Fujita T, van Kooten C, Daha MR (2006) Glomerular activation of the lectin pathway of complement in IgA nephropathy is associated with more severe renal disease. J Am Soc Nephrol 17:1724-1734

10. Faria B, Henriques C, Matos AC, Daha MR, Pestana M, Seelen M (2015) Combined $\mathrm{C} 4 \mathrm{~d}$ and $\mathrm{CD} 3$ immunostaining predicts immunoglobulin (Ig)A nephropathy progression. Clin Exp Immunol 179(2):354-361

11. Espinosa M, Ortega R, Sanchez M, Segarra A, Salcedo MT, Gonzalez F, Camacho R, Valdivia MA, Cabrera R, Lopez K,
Pinedo F, Gutierrez E, Valera A, Leon M, Cobo MA, Rodriguez R, Ballarin J, Arce Y, Garcia B, Munoz MD, Praga M (2014) Association of $\mathrm{C} 4 \mathrm{~d}$ deposition with clinical outcomes in IgA nephropathy. Clin J Am Soc Nephrol 9(5):897-904

12. Mestecky J, Raska M, Julian BA, Gharavi AG, Renfrow MB, Moldoveanu Z, Novak L, Matousovic K, Novak J (2013) IgA nephropathy: molecular mechanisms of the disease. Annu Rev Pathol 8:217-240

13. Oortwijn BD, Rastaldi MP, Roos A, Mattinzoli D, Daha MR, van Kooten C (2007) Demonstration of secretory IgA in kidneys of patients with IgA nephropathy. Nephrol Dial Transplant 22:3191-3195

14. Wyatt RJ, Julian BA (2013) IgA nephropathy. N Engl J Med 368(25):2402-2414

15. Yu XQ, Li M, Zhang H, Low HQ, Wei X, Wang JQ, Sun LD, Sim KS, Li Y, Foo JN, Wang W, Li ZJ, Yin XY, Tang XQ, Fan L, Chen J, Li RS, Wan JX, Liu ZS, Lou TQ, Zhu L, Huang XJ, Zhang XJ, Liu ZH, Liu JJ (2011) A genome-wide association study in Han Chinese identifies multiple susceptibility loci for IgA nephropathy. Nat Genet 44(2):178-182

16. Gharavi AG, Kiryluk K, Choi M, Li Y, Hou P, Xie J, SannaCherchi S, Men CJ, Julian BA, Wyatt RJ, Novak J, He JC, Wang H, Lv J, Zhu L, Wang W, Wang Z, Yasuno K, Gunel M, Mane S, Umlauf S, Tikhonova I, Beerman I, Savoldi S, Magistroni R, Ghiggeri GM, Bodria M, Lugani F, Ravani P, Ponticelli C, Allegri L, Boscutti G, Frasca G, Amore A, Peruzzi L, Coppo R, Izzi C, Viola BF, Prati E, Salvadori M, Mignani R, Gesualdo L, Bertinetto F, Mesiano P, Amoroso A, Scolari F, Chen N, Zhang H, Lifton RP (2011) Genome-wide association study identifies susceptibility loci for IgA nephropathy. Nat Genet 43(4):321-327

17. Feehally J, Farrall M, Boland A, Gale DP, Gut I, Heath S, Kumar A, Peden JF, Maxwell PH, Morris DL, Padmanabhan S, Vyse TJ, Zawadzka A, Rees AJ, Lathrop M, Ratcliffe PJ (2010) HLA has strongest association with IgA nephropathy in genome-wide analysis. J Am Soc Nephrol 21(10):1791-1797

18. Jozsi M, Tortajada A, Uzonyi B, Goicoechea de JE, Rodriguez de CS (2015) Factor H-related proteins determine complement-activating surfaces. Trends Immunol 36(6):374-384

19. Zhu L, Zhai YL, Wang FM, Hou P, Lv JC, Xu DM, Shi SF, Liu LJ, Yu F, Zhao MH, Novak J, Gharavi AG, Zhang H (2015) Variants in Complement Factor $\mathrm{H}$ and Complement Factor H-Related Protein Genes, CFHR3 and CFHR1, Affect Complement Activation in IgA Nephropathy. J Am Soc Nephrol 26(5):1195-1204

20. Onda K, Ohsawa I, Ohi H, Tamano M, Mano S, Wakabayashi M, Toki A, Horikoshi S, Fujita T, Tomino Y (2011) Excretion of complement proteins and its activation marker C5b-9 in $\operatorname{IgA}$ nephropathy in relation to renal function. BMC Nephrol 12:64-122

21. Rosenblad T, Rebetz J, Johansson M, Bekassy Z, Sartz L, Karpman D (2014) Eculizumab treatment for rescue of renal function in IgA nephropathy. Pediatr Nephrol 29(11):2225-2228 